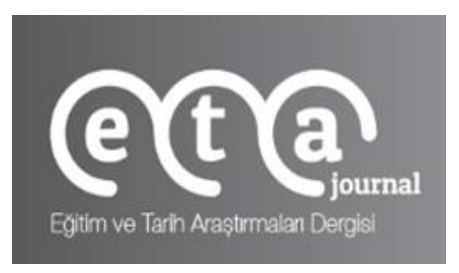

\title{
Orxan ZAMANOV*
}

\section{ULUSLARARASI EĞİTIM VE TARIH ARAŞTIRMALARI DERGISİ}

(ETA JOURNAL)

\author{
INTERNATIONAL JOURNAL OF EDUCATION AND \\ HISTORY RESEARCH
}

Yıl: 4, Sayı: 1, Ocak 2022, s. 9-23.

\section{TARİHÖNCESİ SAVAŞ VE ARAŞTIRILMASI İLE İLGILİ SORUNLAR}

\begin{abstract}
ÖZET
"Tarihöncesi savaş ve araştırmasıyla ilgili sorunlar" başlıklı bu makale, tarih öncesi savaş alanındaki araştırma problemlerinin incelenmesi konusunu ele almaktadır. Yazar, deneysel ve savaş alanı arkeolojisinin yanı sıra kültürel ve fiziksel antropolojiden elde edilen sonuçları kullanarak sorunun kapsamlı bir incelemesinin önemini vurgulamaktadır. Erken dönem çatışmalarıyla ilgili temel bilgimizin neredeyse tamamı arkeoloji ve antropolojiden gelmektedir. Çalışma, tarih öncesi savaşın, ilkel silahların ve disiplinler arası araştırmasının evrimine genel bir bakış sunmakla birlikte, ana bölümü tarih öncesi dönemi inceleme ve araştırma konularına odaklanıyor. Ek olarak, militagenez ve tarih öncesi militarizasyonla ilgili kavramları ve insanlık tarihindeki çatışma ve savaş biçimlerinin ayrıntılarını kısaca analiz ediyor.

Çalışma ayrıca, savaş çalışmaları ve savaşın gelişimi konusunda geniş deneyime sahip yazarın bazı fikirlerini, düşüncelerini ve görüşlerini yansıtmakta ve ilim alanında tarih öncesi savaş sorununu çözmek için disiplinler arası bir yaklaşımın önemini vurgulamaktadır. Bu nedenle yazar yeni bir bakış açısı ve farklı bir dönemlendirme önermektedir. Sonuç olarak makale, tarihsel savaşlar ile diğer savaş ve çatışmalar arasındaki sınırların zaman ve anlam çerçevesinde belirlenmesinin önemini ortaya koymaktadır.

Anahtar kelimeler: ilkel savaş, militagenez, militarizasion, savaş alanları arkeolojisi ve tarihöncesi savaş.
\end{abstract}

\footnotetext{
* Öğr., Gör., Khazar Universitesi, Humanitar, Sosial və Tehsil Elmləri Fakültesi, Tarix və Arxeologiya Departamenti, Bak1/ Azərbaycan və Bilim Elemanı, Azerbaycan Milli Bilimler Akademisi, Arxeologiya və Etnoqrafiya İnstitutu, Elmi-ekspozisiya Bölümü, Bak1/Azərbaycan, orkhan.zamanov@khazar.org .

ORCID: 0000-0001-9367-6736.

*Bu makale Turnitin programı ile taranmıştır.

*Araştırma makalesi.

*Makale geliş: 13.10.2021- Makale kabul: 12.12.2021
} 


\section{THE PREHISTORIC WAR: ITS RESEARCH PROBLEMS}

This article entitled "The Prehistoric war: its research problems" is dedicated to the issue of studying the investigation problems in the field of prehistoric war. The author emphasizes the importance of a comprehensive study of the problem by using results from experimental and battlefield archaeology, as well as cultural and physical anthropology. Our fundamental knowledge of early conflicts comes almost entirely from archaeology and anthropology. The article describes an overview of the evolution of prehistoric warfare, primitive weapons, and its multidisciplinary research. The main part of the article focuses on the issues of studying and researching the prehistoric era. In addition, it has briefly analyzed the concepts related to militagenes and prehistoric militarization, as well as details of the forms of conflicts and wars in human history.

The article also reflects some ideas, thoughts and opinions of the author, who has extensive experience in war studies and evolution of warfare. It highlights the importance of an interdisciplinary approach to solving the problem of prehistoric war in the national science sphere. Therefore, the author propounds a new point of view and a different periodization. In conclusion, the article substantiates the importance of determining boundaries between historical wars and other wars and conflicts within the framework of time and essence.

Key words: Battlefield archaeology, militagenes, militarization, prehistoric war, primitive warfare and warfare.

\section{GíRiş}

Makalede işlenen konu yazarın üzerinde uzun zamandır çalıştığı disiplinler arası bilimsel araştırma alanına ait çalışmaların başlangıç bölümüdür. Savaş ve ona bağlı olarak ortaya çıkan maddi kültür örnekleri arkeoloji biliminin başlıca kaynakları olsa bile, konu üzerine pek çok ülkede, özellikle Azerbaycan, Türkiye, Türkmenistan ve diğer Türk devletlerinin ulusal biliminde teorik-kavramsal araştırmalar yazılmamıştır ${ }^{1}$ (Zamanov, 2017a; Zamanov, 2017b; Oliyev, 2016: 9-69).

Tarih öncesi savaş genel olarak tüm savaşların ve çatışmaların (münakaşaların) kökeninde duran bir prototip olarak ister sosyolojik açıdan isterse de tarihsel açıdan çok önemlidir. (Leblanc, 2020: 39-57). Savaşın kökenini tartışırken ilk önce onun gelişim şekilleri ve tarihte mevcut analojilerinin bahsedilmesi gerekmektedir. Savaşın tarihsel gelişimi direk olarak üretken güçlerin ve toplumun ekonomik durumu ile gerçekleşmiştir. Bu konularla ilgili uzun zamandır farklı felsefi, ideolojik ve politik görüşlerin yanı sıra geniş ekonomik görüşler de mevcuttur. Bu görüşler hakkında yaygın edebiyat ve makaleler olduğundan bu yazımızda tarih öncesi savaşın (prehistoric war) anlamı, tanımı, karakteri (doğası) ve incelenmesi (araştırılması) problemi üzerinde durulmasının önemli olduğu düşünülmüştür. (Zamanov, 2017a: 17; Moseley, 2002; Snesarev, 2013).

Tarih öncesindeki savaşla ilgili ilk düşünceler XVII yüzyılda Hobbs'a ait olduğu görülmektedir. Daha sonra farklı yaklaşımla, XVIII yüzyılda Russo da bu mesele ile ilgili düşüncelerini ortaya koydu. Bu konunun felsefi devamını XIX yüzyılda Hegel, Marks ve Engels'in eserlerinde izlemek mümkündür. XX. yüzyıl bu konuda daha bilinçli ve kritik bir yaklaşım ortaya koymuştur. (Snesarev, 2013: 35-68; Dennen, 1995). İlk önce felsefi-ideolojik

\footnotetext{
${ }^{1}$ Ulusal bilimde teorik-kavramsal çalışmaların yapılması gereği Avrupa ve Amerika, aynı zamanda Rusya merkezci akademisyensiyasetin önüne geçmenin en önemli şartlarındandır.
} 
yazarlar savaş tarihi ve tarih öncesi savaşların araştırılmasından uzaklaşmışlardır. Bu konu ile şimdi genel olarak tarihçiler, arkeologlar, antropologlar, etnograflar, kültür bilimi uzmanları ve sosyologlar ilgilenmişler, buna rağmen genel olarak savaş konusuna yaklaşım ister XIX. yüzyılda ister XX. yüzyılda, isterse de XXI. yüzyılda çok çelişkili ve önyargılı olarak kalmaktadır. $\mathrm{Bu}$ yönde önceden yayınlanmış makalelerimizi göz önüne alarak, tarih öncesi savaşın araştırılması ile ilgili probleme geçiyoruz. (Zamanov, 2017a: 17-20).

Tarih öncesi savaşa geçmeden bir konuya açıklık getirilmesi gerekmektedir. Savaş tarihi zaman içerisinde olan bir süreçdir ve onun kökeni (oluşumu) veya militagenez bilimsel, doğrulanabilir kanıtlarlaincelenmelidir. Tüm tarihi zaman içerikli süreçler - olaylar (etkinlikler), değişimler, evrimler ve mücadeleler muhtemelen gerçekleştiği mekânda (yerde) izler bırakmakta ve bu izler bize somut ve tutarlı kanıtlar sistemi sunmaktadır. Bu kanıtların da incelenmesi görevi, genel olarak arkeoloji ve antropoloji bilimine düşmektedir.

Arkeoloji bilimi savaş ve onunla ilgili konuları genel olarak bilimsel açıdan XX. yüzyılda araştırmaya başlanmıştır. $\mathrm{Bu}$ araştırmaların tam olarak ne zaman düzenli hale geldiğiyle ilgili tartışmalar arkeologlar arasında halen devam etmektedir. Orta Çăg silahları üzerine uzman S. A. Ahmedov’un 2017 yılında basılmış olan araştırmasında "silah arkeolojisinin" veya "askeri arkeolojinin" Evart Oukşott tarafindan 1960 y1lda Londra'da basılmış olan "Silah Arkeolojisi. Tunç Çağından Rönesans Çağına Kadar Silah ve Zırh” isimli kitabıyla askeri tarihin farklı maddi kalıntılara dayanarak araştırılması ile başlandığını öne sürmektedir. Araştırmacıya göre, bu zamana kadar arkeologlar buldukları silahları ülkede yalnız silah üretimi ve metal imalatının gelişimini ortaya koyan buluntular gibi kabul edilmiştir. E. Oukşott'un araştırmalarından sonra arkeoloji silah antropoloji, yazılı, resimli kaynaklar ile karşılaştırılarak ülkenin veya bölgelerin askeri işinin (harp işinin) gelişimini gösteren kaynak gibi kabul edilmeye başlanmıştır. (Ohmədov, 2017: 29). Arkeolog D. Evans "Whole Story"2 serisinde yayınladığı "Çatışma arkeolojisi" (Conflict archaeology) makalesinde ise, savaş alanlarının kazılarına dayanarak savaş arkeolojisinin ilk olarak 1905 yılında İsveç'in Gotland adasındaki Visbi kenti yakınlardaki toplu savaşçı mezarlığının araştırılması ile başlandığını ve düzenli olarak 1970- 80`lerden itibaren İngiltere, Almanya ve Amerika`da devam ettiğine dikkat çekmektedir (Evans, 2017: 510-511). Savaş tarihçisi ve arkeoloğu A.N. Kirpiçnikov’un 1998 yılında St. Petersburg şehrinde gerçekleştirilen "Askeri arkeoloji. Tarihsel ve toplumsal açıdan silah ve askeri işler" isimle uluslararası konferans çalışmalarına eklenen "Askeri arkeoloji: uluslararası ve sosyal önemi” isimli makalesinde askeri arkeolojinin bağımsız bilim dalı olarak XIX. yüzyılın ortalarında Avrupa`da oluştuğu ve genellikle müzelerdeki arkeolojik buluntular sırasındakı silahlar ile bağlılığını vurgulamıştır (Kirpichnikov, 1998: 10-12).

Antropologlar ve onlarla birlikte etnograflar (kültürel ve sosyal antropologlar) savaş ve özellikle tarih öncesi savaş konusuna silahlar ve askeri iş açısından değil savaşın toplumsal ve kültürel aynı zamanda paleopsikoloji ve etolojik yönlerden ele almaya başlamışlar ve bu sebeple

\footnotetext{
${ }^{2}$ Archaeology: the whole story. ed. Paul Bahn. (2017)/The whole story: Archaeology/. London: Thames \& Hudson, p. 574
} 
savaş alanları ve onların doğrudan araştırılması alan çalışmalarında kazı zamanı bulunan antropologlara kalmıştır. Buna rağmen, tarih öncesi savaşla ilgili dikkate değer çalışmalar askeri veya savaş arkeolojisi ile paralel başlatılmıştır (Evans, 2017: 510-511; Pershis, Semenov, Shnirelman, 1994a). Antropologlarla birlikte tarihçilerin, özellikle savaş tarihi uzmanlarının yaklaşımı ilgi çekicidir. Onlar kavram olarak "tarih öncesi savaş" yerine uzun süre "ilkel savaş" (Primitive War, Primitive Warfare, Primordial warfare) terimini kullanmışlardır. Bunun üzerine ABD'de 1940-lardan itibaren ileri çalışmalar yapıldı. İlkel savaş konsepti açısından konuyu en iyi ele alan araştırmacılar C. Keegan, K. Laurens ve D.Dayson olduğu düşünülmektedir (Keegan, 1995; Lawrence, 1996; Dawson, 1996).

Son dönem disiplinlerarası araştırma niteliği taşıyan Avrupa dillerinde yayınlanan bazı kapsamlı çalışmalardan da bahsetmemiz gerekmektedir. Bunlardan biri "Savaş ve Toplum. Arkeolojik, Sosyal Antropolojik Perspektifler" isimli uzman grubunun ortaya çıkardığ 1 derlemedir. İkincisi J. Guilaine ve J. Zammitin yazarı oldukları "Savaşın kökenleri: tarih öncesinde şiddet" eseri ve üçüncüsü ise Cambridge Üniversitesinin "Cambridge Dünya Tarihinde Şiddet" ("The Cambridge World History of Violence") adlı uzman grubunun çok ciltli yayınıdır.

\section{Yöntem ve Veri Toplama Teknikleri}

Söz konusu alan genel olarak "savaş arkeolojisi” gibi tanımlanmakta, bazen askeri arkeoloji veya harp arkeolojisi gibi farklı ülkelerde bilimsel alanda kullanılmaktadır. Bu alan özellikle tarihi arkeolojinin silahlar, savaş (askeri işler), savaş sanatı, askeri mimari ve savaş endüstrisi (harp sanayi) üzerine çalışmalar yapan dalı olmak üzere araştırılan tarihi dönem ile ilgili askeri bilgilerin gelişim düzeyi (durumu) hakkında uzmanlaşmış deneyimin olmasını gerektirir. Tarihsel arkeolojinin tarih öncesi arkeolojisinden (Prehistory archaeology) esas fark1, yazılı kaynakların varlığı olsa da bu durum tüm dünya için aynı derecede geçerli (aktüel) değildir. Bazı bölgelerin ve halkların savaş arkeolojisi yazının ve devletin ortaya çıkmasından önceki dönemi de araştırmaktadır. Aslında (temel olarak) savaş alanlarının arkeolojisi (battlefield archaeology), askeri işler ve silah üretimi sanatı (warfare and weaponry), askeri mimari ve savunma istihkâmları tarihi (military architecture) ve askeri anma (inanç) mekanları ${ }^{3}$ gibi alt bölümlerden oluşan savaş arkeolojisi temelini İkinci Cihan harbinden sonra bilimsel araştırmaların eski (antik) halkların ve uygarlıkların askeri işine, silah üretimine odaklanmasından sonra gelişmiştir (Sutherland ve Holst, 2005; Oakesshott, 1994; Laffin John, 1993; Keegan, 1995).

Savaş arkeolojisinin kaynağını (temelini) ilk olarak silahlar, özellikle savaş alanlarından ve askeri üretim merkezlerinden (komplekslerinden) elde edilen savaş için o devirde kullanışlı silahlar oluşturmaktadır. Tarih, antropoloji, resim ve mimari yönlü kaynaklar da savaş

\footnotetext{
${ }^{3}$ Askeri anım (inanç) mekanları savaş elitasının mezarlarından ta zafer adına inşa edilen yapılanmalara kadar büyük bir alanıkapsıyor. Bura kabile, boy ve aşiret savaş liderlerinin kurqanları, savaşçı mezarlıkları, taş anıtlar, savaş tanrılarına aid edilenmekanlar, zafere itafen yapılan anıtlar, ordu için kutsal önem taşıyan mekanlar ve zafer abideleri dahil edile bilir.
} 
arkeolojisi için gerekli kaynaklar sunuyor (Shapova, 2000; Martinov, 2005; Martinov, 2012; Sevin, 2003;).

Silahlardan sonra en önemli kaynak ve veri kitlesi antropoloji bilimi alanında oluşmaktadır. Bunlara ister rastgele ${ }^{4}$, ister eski savaş alanlarından ${ }^{5}$, ister toplu mezarlık alanlarından ${ }^{6}$, isterse de, kabirlerden bulunan ve üzerinde silahla yapılan şiddet ve cinayet izi bulunan insan kemiklerinin kalıntılarını ve parçaları dahil edilmektedir (Quliyev, 2008; Lawrence, 1996). Çağdaş (Modern) adli tip ve paleoantropolojik analizler soğuk ve ateşli silahla insan vücudunun maruz kaldığı yaralama ve fiziksel hasarla ilgili somut fikirler ortaya çkarabiliyor (Suleymanova, 2000; Faqan ve DeKors, 2007).

\section{Tarih öncesi çağın mücadele koşulları ve gerçekleri}

Paleolitik çağda insanlar arasında çatışmaların olması kaçılmaz bir durum olmasına karşın bu tarz çarpışmalar savaş değildir. Bunlar bireysel ve tür içi çarpışma ve mücadelelerdir. Aynı fikri Mezolitik çağ için desöylemek mümkündür. Bu dönemlerde insan toplumu daha çok olgunlaşmış ve felsefe tarihçisi R.S.Haciyev'in "Tarihi sürecin gelişim dinamiği ve ya küreselleşmeye giden entelektüel evrim yolu" adlı araştırmasında belirttiği gibi, bilinçli entellektüel yaşına geçse de insan hala savaş yapacak düzeyde organizeye ve ekonomik potansiyele sahip değildir. (Hacıyev, 2015: 41-218). Aynı zamanda taş devri insanlarının "silahlanma"sı ile ilgili net ve yeterli bilgi sahibi değiliz. Örnek olarak, M.V. Anikoviç ve V.İ. Timofeev'in "Taş çağında silahlanma ve silahlı çatışmalar" isimli dikkat çekici makalesine göre insan doğası çıkar çatışmalarına eğilimli olsa da Taş çağı sürecinde insanlar arası çatışma ve çarpışma ihtimali Yeni Taş dönemine kadar arkeolojik ve antropolojik buluntularla imkansız görünmektedir. (Anikovich ve Timofeev, 1998; Dennen, 1995).

Paleolitik dönemde silahlı çatışma konusuna dokunmadan geçilmemelidir. İlk olarak, belirtmek gerekir ki, bu dönem ile ilgili net ve doğrulanabilir kanıtlar bulunmamaktadır. Bu aynı şekilde antropoloji için ve arkeoloji için de geçerlidir (Dawson, 1996: 26-29; Lawrence, 1996). Fakat bazı örneklere bakmamız gerekir. Bunlar tarih öncesi döneme ait mağaralardan ortaya çıkarılan ve üzerinde şiddet izleri bulunan insan kemiklerinin kalıntılarıdır. Böyle buluntular Homo erectus türüne ait (Zhukoudian mağarası, Çin), Homo sapiens neanderthalensis türüne ait (Krapina mağarası, Xorvatiya; Mugaret-es-Shul mağarası, Filistin) ve Homo sapiens sapiens türüne ait (Maszycka mağarası, Polşa) farklı mağaralardan ortaya çıkarılmış ve incelenmiş olsa dahi tüm Üst paleolit sanatı (Prehistoric Rock Art) insanların birbirilerine karşı yüzleşme görüntüsü tam bir örnek vermemektedir. (Anikovich ve Timofeev, 1998: 16).

Paleolitik "silahlara" gelince konu daha da karışık bir duruma gelmektedir. Çünkü bu dönem için özel bir silah biçimi bulunmamaktadır. Tüm silahlar aynı şekilde hem av hem çatışma ve çarpışma için de kullanılabilmektedir. Bu yüzden birçok uzmanlar ya tüm silahları

\footnotetext{
${ }^{4}$ Alp dağlarında 1991 yılında ortaya çıkarılan Ötzi Buzadamı buluntusunu örnek verile biliriz (Bogucki, 2017).

${ }^{5}$ ABD-de Montananın Little Bighorn cıvarında veya Almanyanın kuzeyinde Tevtoburq ormanındakı savaş alanlarının araştırılması,Bkz: Duke P. (2017) Battle of the Little Bighorn 1876; Evans D. (2017) Conflict Archaeology.

${ }^{6}$ Polonyada Katın asker qatliam mezarlığı və ya Avrupada Otuzyillik savaş dönemi savaşçı mezarlıkları örnek ola bilir, Bkz:Sanford G. (2005); Evans D. (2017) Conflict Archaeology.
} 
incelemeye dahil etmekte veya hiçbirini dahil etmemektedir. Bu makalede sadece hepsini gözden geçirip ikisi üzerinde durulacaktır. Arkeolojik kalıntılar ve ilkel toplumların antropoloji ve etnografik incelenmesi sayesinde Eski Taş Çağı için belirli bir silahlanma sırası oluşmuş durumdadır. Buraya çubuk şekilli atma ve dövme aletler, farklı uzunluklu mızraklar, ok ve yay ve değişik biçimli bıçak-hançerler dahil edilebilir. Bunların çoğu ahşap ve kemikten yapıldığ1 için günümüze kadar ulaşmadığından ya onların Paleolitik sanatının resimlerine dayanarak, ya da taş uçluklara (başlıklara) esasen araştırmak zorundayız (Anikovich ve Timofeev, 1998: 1617). Bu dönem için belirtilmelidir ki iki silah insanlar arası çatışma açısından daha önemlidir. Bunlar alev ve savaş çubuğudur. Bunlarla normal şartlar içinde savaşa girilmez, ancak tüm dönemlerde ister alev veya ateş püskürten herhangi yakıcı malzeme düşman için tehlike kaynağ 1 olmuştur. Barut kullanımına kadar askerî açıdan yakıcı malzemeler belirli şartlar ve kullanım tekniği oldukça etkili olmaktaydı. Fakat alev insanları hayvanlardan koruyabildiği gibi, diğer insanlardan da koruyabilme niteliğine sahiptir. Savaş çubuğu (ağır sopa) ise yırtıcı hayvan ile yüzleştiğinde kullanılması mümkün olan, ama uzak mesafedeki av hayvanına karşı yetersiz bir silahtır. Her iki "silah" muhtemelen yüz- yüze, karşı-karşıya gelecek taraflar için tehlike kaynağıdır. Hiçbir hayvanı yalnız alev ve çubukla avlamak mümkün olamamıştır. Bunlar ilkel insanlar tarafından onlara saldıracak herhangi tehlikeli düşmana (yırtıcı veya yabani hayvan, farklı insan türü ve başka kabileden olanlar) karşı yeterli koruma ve yakın savaş aleti işlevindeydi. Sonraki dönemlerde gerçek silah gibi kullanılacak balta, mızrak, ok ve yay, bıçak ilk aşamada insan öldürmek için üretilmemiştir. Onlar çok sonradan üretimin gelişmesi sonucunda silahlanmaya alınmış ve dönemin askeri taleplerine uygun şekilde yapılandırılmış ve değiştirilmiştir.

Mezolitik çağ için özellik taşıyan en önemli durum yeryüzünde iklimin değişmesiyle insanların göç etmesidir. Özellikle bu dönemde kabile ve ilkel topluluklar arazi niteliği kazanmaya başladılar. $\mathrm{Bu}$ arkeoloji buluntular ve anıtlar ile doğrulanmıştır. Aynı zamanda arkeolojik kültürler kendine has yayılım sınırları kazanmaya başlamışlardır. Bu sınırların ortaya çıkması kavimler arası rekabeti ortaya çıkarmıştır. Tarih öncesi savaşın nedenleriyle ilgili sorunlardan söz eden araştırmaçı D. Dauson nedenleri maddi değerler ve kaynaklar için rekabet olarak iki bölüme ayırmıştır (Dawson, 1996: 6-19). Aynı zamanda, Mezolitik çă̆ sanatı resimlerinde az da olsa, çatışma sahneleri yer almaya başlamıştır. Av silahları daha gelişmiş ve uzak mesafeli savaş teknikleri ileri bir düzeye gelmiştir. Ama bu dönem "silah" gelişimi avcılık ile bağlı gerçekleşmiş ve toplumun daha üretici düzeye gelmesiyle ilgilidir (Anikovich ve Timofeev, 1998: 17-18)

Taş döneminin son kesiminde sosyal ve ekonomik gelişimin ilk ciddi belirtileri ortaya çıkmış ve Yeni Taş Çağının ilk başlarından insanlığın daha karmaşık ve hiyerarşik toplumsal sisteme geçişinin, tarih öncesi savaşa etkisi ilkel insan için yeni kabile savaşı (tribal warfare) gibi tanımlanan süreci başlatmıştır. ${ }^{7}$ (Vandkilde, 2006; Steuer, 2006; Raymond, 2000).

Yukarıda belirtilen silahlar genel olarak arkeoloji kazılar zamanında bulunan kalıntılar ve izleri göz önüne alarak taktim edilmiştir. Buna rağmen ilk insanların doğal taş (atmak için), alev

\footnotetext{
${ }^{7}$ Bkz: Ferguson R. B. Kabile savaşı (Tribal Warfare) ile ilgili tüm yayınlarına.
} 
(ürkütücü ve yakma silahı gibi) ve nihayetinde kendi diş ve tırnaklarını kullanması daha mantıklı olmalıdır. Bunlar sırasında üzerinde durmak istenilen çarpışma silahı açık alevdir. Tarih öncesi için doğal olmayan ve kontrölü zor bir niteliğe sahip açık alev yapay (doğal olmayan) yolla elde edildikten sonra ilkel topluluk ve kabile için gerçek bir güç kaynağ1 durumuna gelmiştir. O zamana kadar alevin sönmemesi için ilkel insan birliği her şeyi yapıyordu. Tarih öncesi insanların nasıl alevi elde etmeleri bilimde ciddi tartışma konusudur. Ama onun kullanım alanı deneysel arkeologlar ve etnograflar için bilinen konuları içerisindedir. Tarih öncesinde alev en önemli enerji kaynağı idi. O sıcak, 1şık, hayvanlardan korunma veya onları avlama, en önemlisi yemek hazırlamaya imkan vermekteydi. Onu bir çok teknik sorunları çözmek için kullanıyorlardı (Malinova ve Malina, 1988: 122-125; Boriskovskiy, 1980: 84-90; Raymond, 2000).

\section{Tarihöncesi çağda savaşın ortaya çıkmasının önkoşulları}

Her savaş kendiliğinde büyük çaplı ve toplumsal suç olayıdır. Sıradan adli inceleme ve araştırma kısasürede sınırlı bir suçun soruşturulması ve araştırılmasıyla ilgilenir. Tarih boyu çok sayıda baskın, çatışma ve savaşın incelenmesi ve araştırılması ayrıca bilimsel-metodolojik bir yaklaşım gerektirmektedir. (Zamanov, 2017b: 40).

En eski ve ilkel silah örnekleri, avda ve ev üretiminde kullanılan av silahları ve kesici aletlerdir. İnsanların diğer canlıya karşı kullandıkları ilk silah kendini savunma karakterli ilkel kırma, kesme, delme ahşap, kemik, taşdan yapılmış ve vahşi yırtıcı hayvanlardan korunmak için üretilmiş ve kullanılmıştır. Yalnız, bu henüz askeri işler ve dövüş sanatlarının oluşumuna, varlığına delil sayılmaz (Zamanov, 2017b: 41).

Tarih öncesi çağda gerçekleştirdiğimiz araştırma sürecinde militagenez ve militarizasyon ile ilgili gözlemler ve bilimsel gerçeklerin analizi yeni görüşlerin oluşmasına yol açmıştır. İlk olarak savaşların sınıflandırması ve analojilerine bağlı farklı hipotezler ortaya çıkmıştır. Birçok askeri tarih üzerine araştırmacılar (Dyupyui ve Dyupyui, 1997: 1-6; Guilaine ve Zammit, 2005) savaşın en eski zamanlardan, hatta insanların yaratılışından, antropogenezin başından beri varlığını savunsalar bile, bazı gerçekler ve araştırmalar bu bakış açısını kabul etmeye izin vermemektedir. Biz bu konuyu daha öncesinde 2017 yılında çalışma ve makalelerimizde ele aldığımız ve buna ilişkin derinlemesine çalışmalar yapıldığından bu aşamada daha çok savaşın sınıflandırması konusu üzerinde durmayı tercih etdik (Zamanov, 2017b: 43-44; Palmer ve Palmer, 2007: 82-84; Porshnev, 2013).

Böylece, insanlığın en eski zamandan modern çağa kadar olan tarihinde silahlı çarpışmaların (yüzleşmelerin) üç tipini ayırt edebildik. "Silahlı çarpışmalar çoğu sayda bireyin dahil olduğu, organize bir şekilde yürütülen kasıtlı şiddet faaliyetidir" tanımlaması doğru bulunmuştur. Buraya baskınlar (raidings), çatışmalar (conflicts), savaşlar (war) ve onlar ile bağlı elementler - soygun, yağma, silahlı saldırı, silahlı müdahale, katliam, soykırım, saldırı, taaruz, savaş, askeri marş, keşif, seferler, kampanyalar ve operasyonlar dahildir. (Zamanov, 2017b: 45). Makaledeki resimde ilk defa arkeolojik sıralamada genel olarak savaşların dünya tarihindeki dönemsel tablosu sunulmaktadır (Resim.1). Bu tabloyu oluşturmadan önce 2017 
yılında yayınlanmış makalemizde (Zamanov, 2017b) savaşların dönemsel sınıflandırma ve gelişimine göre bölerken eski terminoloji ${ }^{8}$ kullanılmıştır. Fakat daha çağdaş ve rasyonel kavramların kullanımı uygun bulunmuş ve bu kavramlar söz konusu olan tabloya dahil edildi. Bu tabloda savaşlar dönemselsınıflandırma ve gelişimine göre aşağıdaki gibi bölünmüştür:

1. Tarih öncesi savaşlar (Prehistoric war) - tahmin edilen dönem 9000-2500 yıl önce.

2. Tarihsel savaşlar (Classic/Historic war) - tahmin edilen dönem 2500 yıl önce - şimdi.

3. Tarih ötesi savaşlar (Technogenic warfare/Post-historical war) tahmin edilen dönem şimdilik bellideğildir.

Bugün için en iyi incelenmiş ve araştırmalara ciddi kaynak olma kapasitesine sahip savaşlar kesinlikle "tarihsel savaşlar”dır. Onlar milattan önce yaklaşık olarak XV. veya XIII. yüzyıllarda (M.Ö. II binyılın ortaları) başlamış çağımızın XX. yüzyılına gibi devam etmiştir. Çağdaş savaşların kendi teknolojik ve küresel karakterinden kaynaklanan dünya için ölçülemez bir felaket olma durumu vardır (Kreveld, 2005; Zamanov, 2017b: 45; Palmer ve Palmer, 2007: 337). Bu yüzden çağdaş bilim alanları, özellikle yeni oluşan bilim dalları savaş konusuna ve sorununa eğilmek zorundadırlar.

Yukarıdaki kronolojik listede tarih öncesi savaşların (Prehistoric war) tahmini olarak 9000 yıl önce başladığını belirtmiştik. Bunun bilimsel açıklaması elbette mevcuttur. Arkeolojik ve antropolojik kanıtlar Yakın ve Orta Doğuda hayatın tüm alanlarında askeri işin ve savaş sanatının ortaya çıktığını doğrulamaktadır. Bu kanıtlara Eriha'nın taş duvarı (Jericho, 8000 B.C.), taş balta ile katl edilen savaşçı mezarlığı (Talheim, 5000 B.C.), arsenik bakırdan kılıç ve mızrak başlığı (Arslantepe, 4000 B.C.), obsidyen ve çakmaktaşı başlıklı ok ve mızrak izleri olan insan kemikleri ve bu gibi çoğu sayıda buluntular eklendiğinde tahmini bile olsa, bir başlangıç noktası belirlenebilmektedir. Özellikle bu dönemde insanlar arası ve toplumlar arası sosyal farkların ortaya çıkması bir rekabet ve çelişki daha ileride bir kavga ve çatışma ortamı oluşturuyordu. Dünyanın arkeoloji kültürlerden oluşan bir mozaik gibi insan toplumları ile donatılması çağı Neolit ile ilgilidir. En önemlisi yerleşik hayat tarzı tarım ve sanatın gelişimine itici bir etki oluşturmuştur. Yeni Taş Çağının sonuna göçebe hayvancılık ile bağlı üretimin gelişimi ve yaygınlaşması ile daha kritik bir ortam oluşmuş oldu. Üstelik Bronz Çağında gerçekleşmiş teknolojik ve kültürel irelileyişi ve toplumun sosyal düzeninin kökünden değişerek, hiyerarşik kentsel ve uygar devletlerin oluşumu, aynı zamanda yazının ve metalin keşfi ilkel savaş ve militarizasion geleneğinin politik militokrasiye ve tarihsel (klassik) savaşlara geçişini şartlandırmış oldu(Dawson, 1996; Frangipane, 2002; Evans, 2017; Leblanc, 2020; Oakesshott, 1994; Quliyev, 2008; Sevin, 2003; Boriskovskiy, 1980; Qorbatov, 2005; Ismailzade, 2008; Martinov, 2012; Pershis, Semenov, Shnirelman, .1994a; Pershis, Semenov, Shnirelman, 1994b; Faqan ve DeKors, 2007).

\section{SONUÇLAR}

\section{Resim 1:}

${ }^{8}$ Girişte belirtirdiyi gibi eski Sovyetler birliğinden olan ülkelerde "ilkel savaş" (primitive war) kavramı kullanılır. Fakat şimdikimakalede Prof. Q.S. İsmayılzadenin tavsiyesile "tarih öncesi savaş" kavramı kullanılması öngörüldü. 


\begin{tabular}{|c|c|c|c|}
\hline Dönemler & $\begin{array}{c}\text { Kronoloji } \\
\text { tarihler }\end{array}$ & $\begin{array}{c}\text { Yarım } \\
\text { dönemler }\end{array}$ & Kriterler \\
\hline \multirow{3}{*}{$\begin{array}{l}\text { Tarihsonrası (Tarihöncesi)savaşlar } \\
\text { Bilinç ve biliçgücü }\end{array}$} & & $?$ & $\begin{array}{c}\text { Uzay teknolojileri } \\
\text { Yari robot askeri araçlar }\end{array}$ \\
\hline & & & Teknojenlik, Robotizasiyon \\
\hline & \multirow{2}{*}{$\begin{array}{c}\text { M.S. } \\
\text { XVIIXVII } \\
-X X X X X I \\
\text { yüzyıllık }\end{array}$} & Geçiş dönemi & $\begin{array}{c}\text { Bilişim teknolojileri (İT) } \\
\text { Nükleer silahlar } \\
\text { Sanayileşme } \\
\end{array}$ \\
\hline \multirow{4}{*}{$\begin{array}{l}\text { Tarihsel savaşlar Becerilerin, } \\
\text { fiziksel ve } \\
\text { zihinsel gücünkombinasyonu }\end{array}$} & & 3. yarı dönem & $\begin{array}{c}\text { Cebhe taktii } \\
\text { Strateji-Operatif-Taktik }\end{array}$ \\
\hline & $\begin{array}{l}\text { M.S. X\XIII } \\
- \text { XVI\XVII } \\
\text { yüzyıllık }\end{array}$ & 2. yarı dönem & $\begin{array}{c}\text { Manevra } \\
\text { taktii } \\
\text { kampanya } \\
\text { Şövalyelik } \\
\end{array}$ \\
\hline & \multirow{2}{*}{$\begin{array}{l}\text { M.Ö.XV\XIII } \\
\text { yüzyıllıkten - } \\
\text { M.S. XIXIII } \\
\text { yüzyılla gibi }\end{array}$} & 1. yar1 dönem & Yürüyüş taktii \\
\hline & & \multirow[t]{2}{*}{ Geçiş dönemi } & $\begin{array}{r}\text { İstihbarat ve keşif } \\
\text { taktiMilitakrasi }\end{array}$ \\
\hline \multirow{4}{*}{$\begin{array}{c}\text { Tarihöncesisavaşlar } \\
\text { Fiziksel güçve beceriler }\end{array}$} & \multirow[b]{2}{*}{$\begin{array}{l}\text { M.Ö. III-II } \\
\text { biny1ll1klar }\end{array}$} & & Nizami ordu \\
\hline & & $\begin{array}{c}\text { Eski } \\
\text { devletçilik } \\
\text { dönemi } \\
\text { savaşları }\end{array}$ & Ordu \\
\hline & $\begin{array}{l}\text { M.Ö. V-IV } \\
\text { biny1llıklar }\end{array}$ & $\begin{array}{c}\text { Erken } \\
\text { devletçilik } \\
\text { dönemi } \\
\text { savaşları } \\
\end{array}$ & $\begin{array}{l}\text { Baskın, raiders ve } \\
\text { pusuAskeri } \\
\text { demokrasi }\end{array}$ \\
\hline & $\begin{array}{l}\text { M.Ö. VIII-V } \\
\text { binyıllıklar }\end{array}$ & $\begin{array}{l}\text { Devletçilikte } \\
\text { nönceki } \\
\text { dönem } \\
\text { savaşları }\end{array}$ & $\begin{array}{l}\text { Kabile } \\
\text { savaşları } \\
\text { Askeri iş }\end{array}$ \\
\hline
\end{tabular}

Sonuç olarak belirtilmeli önemli husus arkeolojinin genel olarak savaş konusu haricinde tarih bilimi ve kriminoloji ile bağları çok yaygın değildir. Ama silahların üretildiği ve kullanıldığ 1 dönemin gerçekliğine uygunluğu açısından savaş alanlarının incelenmesinde bahsedilen bilim dalları ciddi öneme sahiptirler (Zamanov, 2017; Sutherland ve Holst, 2005). Dönemsellik ve kronolojik problemle bir arada ilk devletleşme ${ }^{1}$ ve erken

\footnotetext{
$1 \mathrm{Bu}$ soru etrafinda ciddi çalışmalar gerçekleştirilmiştir. Bk.: Frangipane, M. Yakın Doğuda devletin doğuşu., Qrinin L.E.Qosudarstvo i istoricheskiy prosess: Epoxa formirovaniya qosudarstva: Государство и исторический процесс: Эпоха формирования государства:\, 2007, 272 с.
} 
küreselleşme ${ }^{2}$ sorunları araştırılan konuyla bağlantılı olan problemlerdendir (Frangipane, 2002; Qrinin, 2007: 161-168; Quliyev, 2008;).

İkinci en dikkat çeken konu, ordu gibi hiyrearşik ve disiplinli bir organizasyonun gelişmesidir. Gerçek savaş ordu ile yapılır. Ordu hiçbir zaman bir insan yığını ve kitlesi olmamıştır. Mahsusi olarak, ordunun devletleşme süresinde etkisi daha ağırlıklıydı. Çünkü, kendi kendine hiç bir devlet siyasi-örgütsel fenomen gibi oluşamazdı. İlk devlet kurumları daha çok aile müessisesi gibi oluşuyordu. İdari iş çiftçilik veya ev işlerini çözmek üzere düzenlenmişdi. Ekonominin ve savaş tehlikesinin etkinlik kazanması ile daha güclü ve düzenli bir idari-iktidarın ve yönetimin ortaya çıkması gerekirdi. Çünkü ticari ilişkileri ve askeri birlikleri yönetmek artık olgun bir devlet talep ediyordu. Bu yüzden hakiki devlet orduya sahip oldukça olgun bir siyasi sistem haline gelebilirdi. Örnek olarak, tüm eski dünyanın ticari merkezlerinin şehir devletlere geçmesi veya göçebe kavimlerin savaş sanatına ve askeri işe sahiplenmesiyle büyük devletler kurabilmeleridir (Vandkilde, 2006; Steuer, 2006).

Tüm belirtilen sorunları sonuçlandırarak öncelik vermemiz gereken konu kritik bilimsel yaklaşım ve disiplinlerarası metodolojiye dayalı araştırmalardır. Çağdaş dönemde askeri işin ve savaş sanatının incelenmesi ciddi ilgi ve aktüellik kazanmıştır. Bunu doğru yönde ve şekilde kullanılması gerekmektedir.

\section{Tartışma}

Günümüzün değişen dünyasında en acil ve çözülmemiş sorunlardan biri, devletlerin askerileştirilmesi ve askersizleştirilmesidir. Çağdaş dönemde, silahlanma taraftarları ile silahsızlanma taraftarları (pasifistler) arasındaki çelişkiler özellikle önemli hale gelmiştir. Bu sebeple, önceki yılların ve yüzyılların aksine, modern silahlar artık insanlığın, doğanın ve gezegenin varlığını tehdit edebilmektedir. Bu durum, bilim ve teknolojinin gelişmesiyle daha da kötüleşmekte, her yıl küresel bir tehdit düzeyine ulaşmaktadır. Böyle bir durumda, nükleer silahlı devletlerin veya kimyasal-biyolojik silahlara sahip herhangi bir kuvvetin yürüttüğü savaş, insanlığın tarihboyunca ve hatta iki dünya savaşı sırasında olduğundan çok daha fazla zarara uğrayacağ ortaya koymaktadır. Ama insanlık tarihsel gelişimi içerisinde savaşlar, muharebelerden yan geçip bugünkü gelişimine ulaşabilir miydi? Genel olarak askeri işin (hərb iş, warfare) ortaya çıkışı, hangi gereklilik ve sebeplere bağlı oldu ki, şimdiki zaman sürecinde insan uygarlığının edindiği silahlarla gezegeni defalarca yok etme gücüne sahip oldu. Buna yol açan faktörler arasında uygarlığımızın bel kemiği ve asıl yaratıcısı olan ekonomi ilk sırada yer almakta mıdır? Birçok uzman, Orta Doğu'da Yeni Taş Devri'nde üretken bir ekonominin ortaya çıkması, ekonomik çıkarların ve daha iyi yaşam koşullarının gerçekleştirilmesi için siyasi çıkarların ve bu çıkarlara ulaşılması

\footnotetext{
${ }^{2}$ Erken (ilk) küreselleşme /First Globalization/ konusu Neolitik dönemin arkeolojisinin çağdaş konusu haline gelmiş ve Batı araştırmacılarının uyarlığın yayılması ile ilgili bakış açısını tamamlıyor. Bu konu ile B. Helving, F. Guliyev, F. Hüseynov, B. Lyonnet ve başka arkeologların yayınlarına bakılması daha uygundur.
} 
için savaşın bir araç olmasını savunmaktadır. Diğer bir uzman grubu ise insan evriminin ve doğasının savaşı ortaya çıkaran neden gibi görünmektedir. Bu konuda hatta uygarlığı ve kültürü esas neden olarak gören araştırmacılar da az değildir. $\mathrm{Bu}$ konular uzun vadeli tartışma konusu olsa bile netleştirebileceğimiz bir sorun vardır. $\mathrm{Bu}$ bilimsel, teknik gelişim ve devrim çağında savaş ve askeri tarihin yeniden incelenmesinde bilgisayarların ve matematiksel yöntemlerin uygulanması ve geçmişin farklı metodoloji ile çalışması eğilimi kuvvetlenmiştir. Ancak karşılaşılan sorunların çözümüne farklı uzmanlık ve mesleklerin ortak faaliyetleri, karşılıklı görüş alışverişi ve son olarak adaptif yayınların baskısı ile ulaşılacaktır (Steuer, 2006; Zamanov, 2017b; Palmer ve Palmer, 2007: 337-343; Guilaine ve Zammit, 2005).

\section{KAYNAKÇA}

BOGUCKİ P. (2017), “Ötzi the İceman”, In: Brian Fagan \& Paul Bahn. (ed.) Archaeology: the whole story, London: Thames \& Hudson, 574 pp.

DAWSON D. J. (1996), The origins of western warfare: Militarism and morality in the ancient world. Boulder: Westview Press, $214 \mathrm{pp}$.

DENNEN, J. M. G. V. D. (1995), The origin of war: the evolution of a malecoalitional reproductive strategy. Groningen: GUP, $843 \mathrm{pp}$.

DUKE P. (2017), "Battle of the Little Bighorn 1876”, In: Brian Fagan \& Paul Bahn. (ed.) Archaeology: the whole story, London: Thames \& Hudson, 574 pp.

ӘНМӘDОV S.Ә. (2017), Azərbaycan silahları IX-XVII əsrlərdə: təkamül və inkişafi, Bakı: Afpoliqraf, $538 \mathrm{~s}$.

ӘLIYEV N. A. (2016), Azərbaycan tarixçilərinin elm əsərlərində hərbi məsələlər. Biblioqrafik göstəricisi, Bakı: Hərbi Akademiya, 117 s.

EVANS D. (2017), "Conflict Archaeology", In: Brian Fagan \& Paul Bahn. (ed.) Archaeology: the whole story, London: Thames \& Hudson, 574 pp.

FRANGIPANE, M. (2002), Yakın Doğuda devletin doğuşu, /italyanca çev.Z.Z.İlkgelen. İstanbul: Kanaat Basımevi, 326 y.

GUİLAİNE J., Zammit J., (2005), The Origins of War: Violence in Prehistory, Trans. By Melanie Hersey, Blackwell Publishers, Malden, Massachusetts, 282 pp.

HACIYEV R. S. (2015), Tarixi prosesin inkişaf dinamikası vo ya qloballaşmaya aparan intellektual təkamül yolu, Bakı: Khazar University Press, $351 \mathrm{~s}$.

\section{ULUSLARARASI EĞİTIM VE TARİH ARAŞTIRMALARI DERGİSI} (ETA JOURNAL) 
KEEGAN D.P.J. (1995), Savaş Sanatı Tarihi, çev: F. Doruker, İstanbul: Sabah Kitaplar1, $621 \mathrm{~s}$.

LAFFIN J. (1993), Digging up the Diggers' War, Singapore: Fong and Sons Press, 106 pp.

LAWRENCE H. K. (1996), War before Civilization: The Myth of the Peaceful Savage, New York: Oxford University Press, 246 pp.

LEBLANC S. (2020), "The Origins of Warfare and Violence", In: (Ed.) Garrett G. Fagan, Linda Fibiger, Mark Hudson, Mattheï Trundle. The Cambridge World History of Violence, Volume 1: The Prehistoric and Ancient Worlds, Cambridge: Cambridge University Press, 740 pp. 39-57 p.

MOSELEY D. A. (2002), A Philosophy of War, New York: Algora Publishing, 266 pp.

OAKESSHOTT R.E. (1994), The Archaeology of weapons. Arms and Armour from Prehistory to the Age of Chivalry, $310 \mathrm{pp}$.

QULIYEV F.E. (2008), Azərbaycanın kurqan qəbirlərində at dəfni, Bakı: Elm, 300 s.

RAYMOND C. K. (2000), Warless Societies and the Origins of War, Ann Arbor: University of Michigan Press, 208 pp.

SANFORD G. (2005), Katyn and the Soviet Massacre of 1940 Truth, Justice and Memory, London: Routledge, 230 pp.

SEVİN V. (2003), Anadolu Arkeolojisi. Başlangiçtan Perslere kadar, İstanbul: DER, $308 \mathrm{y}$.

STEUER H. (2006) "Warrior Bands, War Lords, and the Birth of Tribes and States in the First Millennium $\mathrm{AD}$ in Middle Europe", In: Warfare and Society. Archaeological and Social Anthropological Perspectives, (Ed.) Otto T., Thrane H. and Vandkilde H. Aarhus: AUP, 529 pp. 227-236 p.

SUTHERLAND T.and HOLST M. (2005), Battlefield Archaeology: A Guide to the archaeology of conflict. Practical Guide Series 8. York: BAJR, 67 pp.

VANDKİLDE H. (2006), "Warfare and pre-State Societies: An Introduction", In: Warfare and Society. Archaeological and Social Anthropological 
Perspectives, (Ed.) Otto T., Thrane H. and Vandkilde H. Aarhus: AUP, 529 pp. $105-111 \mathrm{p}$.

ZAMANOV O. A. (2017a), "Müharibə, onun mənşəyi və öyrənilməsi (Tarixşünaslıq və mənbəşünaslıq)", Azərbaycan Arxeologiyası, 20, N1, 17-40. Bakı: Khazar University Press

ZAMANOV O. A. (2017b), “Azərbaycanda tunc dövrü hərb işinin öyrənilməsinin tarixşünaslığı" , Azərbaycan Arxeologiyası, 20, N2, 38-51. Bakı: Khazar University Press

ANİKOVİCH M.V., Timofeev V.I. (1998), "Voorujenie i voorujennie konflikti v kamennom veke \Вооружение и вооруженные конфликты в каменном веке〉", Военная археология. Оружие и военное дело в исторической и социальной перспективе. Ответ ред. В.М. Массон. Международной конференции 2-5 сентября 1998 г. Санкт-Петербург, Россия. СПб.: Гос. Эрмитаж, 344 с, сc. 16-20.

BORİSKOVSKIYY P.I. (1980), Drevneyshee proshloe chelovechestva Древнейшеe прошлое человечества), Москва: Издательство Наука, 230 с.

QORBATOV V.M. (2005), Drevnee orujie i dospex (po materialam drevnix pamyatnikov Ukraini) Древнее оружие и доспех (по материалам древних памятников Украины)\, Часть І. Время меди/ В. М. Горбатов, М. В. Ступко, Е. Я. Туровский. - Симферополь: Новая Эра. 196 с.

QRININ L.E. (2007), Qosudarstvo i istoricheskiy prosess: Epoxa formirovaniya qosudarstva: Obshiy kontekst sosialnoy evolusii pri obrazovanii qosudarsta|Государство и исторический процесс: Эпоха формирования государства: Общий контекст социальной эволюции при образовании государства\, Москва: КомКнига, 272 с.

DYUPYUİ E.R., DYUPYUİ T.N. (1997), Vsemirnaya istoriya voyn: Harperskaya ensiklopediya voennoy istoriilВсемирная история войн: Харперская энциклопедия военной истории, кн. первая 3500 год до Р.Х. - 1400 год от P.X Санкт-Петербург: Москва: Полигон, АСТ, 937 с.

\section{ULUSLARARASI EĞİTIM VE TARİH ARAŞTIRMALARI DERGİSI} (ETA JOURNAL) 
ISMAİLZADE Q.S. (2008), Azerbaydjan v sisteme rannebronzovoy kulturnoy obshnosti Kavkza\Азербайджан в системе раннебронзовой культурной общности Кавказа\, Баку: Nafta- Press, 304 с.

KİRPİCHNIKOV A.N. (1998), "Voennaya arxeoloqiya: ee mejdunarodnaya, nauchnaya I obshestvennaya znachimost।Военная археология: ее международная, научная и общественная значимость|", Военная археология. Оружие и военное дело в исторической и социальной перспективе. Ответ ред. В.М. Массон. Международной конференции 2-5 сентября 1998 г. СанктПетербург, Россия. СПб.: Гос. Эрмитаж, 344 с, сс. 10-12.

SULEYMANOVA D.I. (2000), Криминалистика|Kriminalistikal, Баку: Ишыг, 680 c.

KREVELD, M. V. (2005), Transformasiya VoynilTрансформация Войны, Пер. C Англ. Ано «ИРИСЭН». Москва: Альпина Бизнес Букс, 344 с.

MALINOVA R., MALINA Y., (1988), Prijok v proshloe: Eksperiment raskrivaet tayni drevnix epoxไПрыжок в прошлое: Эксперимент раскрывает тайны древних эпох\, Пер. с чеш.; И.И. Поп и Ю.И. Ритчик. Москва: Мысль, 271 c.

MARTINOV A.I. (2012), Arxeoloqiya \Археология〉, Учеб. Москва: Изд.Юрайт, $460 \mathrm{c}$.

PALMER Dj, PALMER L. (2007), Evolusionnaya psixoloqiya. Sekreti povideniya Homo sapiens\Эволюционная психология. Секреты поведения Ното sapiens〉, /пер.с анг.А.Кулаков, И.Павлова, С.Рысев. Санкт-Петербург: Прайм-ЕВРОЗНАК, 384 с.

PERSHİS A.I. , SEMENOV Y.I. , SHNİRELMAN V.A. (1994a), Voyna i mir v ranney istorii chelovechestva|Война и мир в ранней истории человечества\, Т. 1. Москва: Институт этнологии и антропологии РАН. 176 с.

PERSHIS A.I., Semenov Y.I., Shnirelman V.A. (1994b), Voyna i mir v ranney istorii chelovechestvalВойна и мир в ранней истории человечества), Т. 2. Москва: Институт этнологии и антропологии РАН. 247 с. 
PORSHNEV B. F. (2013), O nachale chelovecheskov istorii (problemi paleopsixoloqii) $\quad \backslash O$ начале человеческой истории (проблемы палеопсихологии)\, Москва: Академический Проект; Трикста, 542 с.

SNESAREV A. E. (2013), Filosofiya voyni ІФилософия войны, Москва: Ломоносовъ, 288 с.

FAQAN B., DEKORS K. (2007), Arxeologiya. V nachalelAрхеология. В началеl, /пер.с англ. Н.Ю.Струкова. Москва: ТЕХНОСФЕРА, 592 с.

SHAPOVA Y.L. (2000), Vvedenie $\mathbf{v}$ veshevedenie: estestvennonauchniy podxod $\mathbf{k}$ izucheniyu drevnix veshey $\backslash$ Введение в вещеведение: естественнонаучный подход к изучению древних вещей\, Москва: Издательство Московского университета. $144 \mathrm{c}$. 